\title{
Tıbbi Cihaz Yatırım Kararlarının Maliyet Fayda Endeksine Göre Değerlendirilmesi
}

\author{
The Evaluation of the Decisions of Medical Device Investment According to Cost-Benefit Index
}

Bülent Soylular ${ }^{1}$, İsmail Ağırbaș²

Ankara Üniversitesi Sağlık Kurumları Yönetimi BD. Doktora Programı Öğrencisi

2 Ankara Üniversitesi Sağlık Bilimleri Fakültesi Sağlık Kurumları Yönetimi AD.
Amaç: Bu çalıșmada Ankara'da bir üniversite hastanesine alımı planlanan Dijital Röntgen Sistemi, Laporoskopi/Endoskopi Sistemi ve Göz Retina Tomografisi projelerinin 2012 yılı verileri kullanılarak maliyet fayda endeksi yöntemi ile değerlendirilmesi amaçlanmıștır.

Yöntem: Projelerin ekonomik ömrü boyunca sağlayacağı gelirler, günlük ve yıllık ișlem sayıları ile hastane bilgi sisteminden alınan bilgiler doğrultusunda hesaplanmıștır. Sağlık Uygulama Tebliği (SUT) fiyatları ve Türk Tabipler Birliği Rehber Ücret Tarifesi baz alınarak iki farklı biçimde yıllar itibariyle gelire ilișkin beș yıllık hesaplamalar yapılmıștır. Projelerin ekonomik ömrü boyunca olușan giderler; hastane bilgi sisteminden, satın alma biriminden ve firma görüșmeleri sonucu elde edilen veriler kullanılarak hesaplanmıștır. Yatırım projesi değerlendirme yöntemi olarak maliyet-fayda endeksi yöntemi kullanıımıștır.

Bulgular: Maliyet-Fayda Endeksi (MFE)'ne göre SUT fiyatları esas alınarak yapılan değerlendirmede yatırım yapılabilecek tek proje Laporoskopi/Endoskopi Sistemi projesidir. TTB Rehber Ücret Fiyat Tarifesine göre her üç projenin maliyet fayda endeksi de pozitif olarak hesaplanmıș ve projelerin öncelik sırası belirlenmiștir. Buna göre öncelik sıralaması; Laporoskopi/Endoskopi Sistemi Projesi, Dijital Röntgen Sistemi Projesi, Göz Retina Tomografi Sistemi Projesi șeklinde olmaktadır.

Sonuç: Proje değerlendirme teknikleri sağlık kurumları finansal yöneticilerine farklı açılardan değerlendirme yapma imkânı sağlayan etkili bir araçtır. Maliyet fayda endeksi yöntemi sağlık kurumlarının yapısına daha uygun olduğu için değerlendirmelerde bu yöntemin esas alınması yararlı olacaktır. Hastane yönetimi, proje seçimini maliyet fayda endeksine göre belirlediğinde yatııma ayıracağı kıt kaynaklarını rasyonel olarak kullanacak ve maksimum faydayı sağlayan projeye yatırmıș olacaktır.

Anahtar Sözcükler: Maliyet Fayda Endeksi, Tıbbi Cihaz, Yatırım Kararı.

Purpose: This study aims to evaluate projects of Digital X-ray System, Laparoscopy/Endoscopy System and Eye Retina Tomography, which are planned to buy for a university hospital in Ankara, by using the data of the year 2012 with the method of cost-benefit index

Methodology: The income that it would be provided along with the economic life of the project was calculated according to their daily and yearly process numbers and the information obtained from the hospital information system. Five years income calculation projections were conducted in two different ways based upon the costs of Medical Enforcement Declaration, and the directory wage scale of Turkish Medical Association. The expenses that occur along with the economic life of the project was calculated by using the data acquired from the hospital information system, purchasing department and interviews with companies. The costbenefit index was used for the evaluation of the investment projects

Findings: In evaluating based on the costs of Medical Enforcement Declaration, the only project that it would be invested is Laparoscopy/Endoscopy System project according to the costbenefit index. According to the directory wage scale of Turkish Medical Association, each costbenefit index of three projects was calculated as positive and priority rank of the projects was determined. The ranking is as follows: the project of Laparoscopy/Endoscopy System, the project of Digital X-ray System and the project of Eye Retina Tomography System.)

Conclusion: The project evaluation techniques are effective tools providing the opportunity to the financial administrators of the healthcare institutions to make assessment from different aspects. Since the method of cost-benefit index is more appropriate for the structures of healthcare institutions, it will be more useful to take as a basis for the assessments. When the hospital managers determines the choice of the project according to the cost-benefit index, they will use scarce resources reserved for the investment in a rational way, and they will invest resources to a project that will provide the maximum benefit).

Key Words: Cost Benefit Index, Medical Device, Investment Decision.
Uz.Bülent SOYLULAR

TSK Saglık Komutanlığı Lojistik Șube Müdürlüğü, 06550

Bakanliklar/Ankara

Telefon: 03124024157,05337331146

E-posta: bulentsoylular@hotmail.com 
Sağlık kurumlarının varlıklarını devam ettirmeleri, büyümeleri ve kurum değerlerini arttırmaları sınırlı kaynaklardan maksimum fayda sağlayacak şekilde yatırım kararlarını ilk seferde doğru vermelerine bağlıdır (1). Modigliani ve Miller; (2-4) yattrım kararlarının yöneticilerin almak zorunda olduğu en önemli kararlar olduğunu, doğru yatırım kararı veren kurumların firma değerini en yükseğe çıkaracağını belirtmiştir. Bu nedenle sağlık kurumları açısından yatırım projeleri stratejik öneme sahiptir ve çok iyi hazırlanmalı$\operatorname{dir}(5)$.

Yatırım projeleri hazırlanırken kurumun kendi kapasitesi, sağllk sektörünün genel durumu, geri ödeme kurumlarının politikaları, diğer sağlık kurumlarinın konumları, toplumun sağllk göstergeleri ve geleceğe yönelik talep tahminleri $(6,7)$ dâhil olmak üzere gereken bütün araştırmalar yapılmalıdır. Hangi projeye yatırım yapılacağına karar verilirken, proje değerlendirme tekniklerinden yararlanılması sağlıklı karar verilmesine katkı sağlayacaktır. Bu çalışmalar sermaye bütçelemesi kapsamında değerlendirilmektedir.

Sağlık kurumlarında sermaye bütçelemesi, sağlık hizmeti üretiminde ihtiyaç duyulan maddi duran varlıklar için yapılacak yatırımlar sonucu gerçekleșecek nakit çıkışların ve bu yatırimlardan elde edilecek nakit girişlerin değerlendirildiği süreç olarak ifade edilmektedir $(1,8)$.

$\mathrm{Bu}$ süreçte bilimsel esaslardan yararlanarak doğru karar veren sağlık kurumları sektörde avantajlı konumda olacaklardır. Sermaye bütçelemesinde kullanilan yöntemlerin bir kısmı paranın zaman değerini dikkate almazken, bir kısmı paranın zaman değerini göz önünde bulundurmaktadır $(1,5,9,10)$. Burada çalışmanın kapsamına uygun olarak paranın zaman değerini göz önünde bulunduran yöntemler kısaca açıklanmıştır Bu yöntemler beş başlık altında incelenebilir. Bunlar:

- Net Bugünkü Değer Yöntemi (Net Present Value),

- İç Verimlilik/İç Kârlılık/İç Getiri Yöntemi (Internal Rate of Return),
- Karlilik Endeksi (Profitability Index),

- Maliyet Fayda Endeksi Yöntemi (Cost-Benefit Index),

- Ekonomik Katma Değer Yöntemi (Economic Value Added)'dir.

Net Bugünkü Değer Yöntemi (Net Present Value)

Bir yatırım projesinin net bugünkü değeri, belli bir iskonto oranına indirgenmiş gelirlerin toplamı ile indirgenmiş giderlerinin toplamı arasındaki farktır (9). Yatırım projesi çalışmalarında proforma nakit akım tabloları bir projenin ilgili tüm nakit giriş ve çıkışlarını bir bütün olarak gösterdikleri için, net bugünkü değer hesapları bu tablolardaki net nakit akımlarının yıllara göre dağılimina dayalı olarak hesaplanir. Önerilen bütün projeler aynı şekilde değerlendirilir ve net bugünkü değerlerine göre büyükten küçüğe doğru siralanırlar $(11,12)$.

\section{İç Verimlilik/İç Karlılık/İç Getiri Oranı Yöntemi (Internal Rate of Return)}

İç verimlilik oranı yöntemi, yatırım projelerinin değerlendirilmesinde zaman faktörünü ve yatırımın ekonomik ömrünü dikkate alan, yatırımın sağlayacağ1 nakit girişleri ile nakit çıkışlarını aynı zaman düzeyine indirgeyerek birbiriyle karşılaştırabilir duruma getiren yöntemdir. $\mathrm{Bu}$ yöntemde, net bugünkü değeri sıfira eşitleyen bir iskonto oranı (13)-hesaplanmakta ve hesaplanan bu orana iç verimlilik oranı denilmektedir. İç verimlilik oranı yatırım projesinden beklenilen karlilik oranından yüksek ise yatırım önerisi kabul edilir. Dolayisiyla bu yöntemde önceden belirlenen kârlılık oranı önem arz etmektedir. Önceden belirlenen kârlılık oranı hiçbir zaman kurumun iskonto oranı olan sermaye maliyetinden düşük olmamalıdır $(1,5,9)$.

Karlılık Endeksi (Profitability Index)

Fayda maliyet oranı yöntemi olarak da bilinen karlılık endeksi, bir yatırım projesinin ekonomik ömrü boyunca sağlayacağı net nakit girișlerinin net bugünkü değeri, yatırım projesinin başlangıç yatırım tutarına bölünmesiyle hesaplanmaktadır (14). Kârlllık endeksinin, birden büyük olduğu projelerde net bugünkü değer sıfirdan büyüktür. Bire eşitse, net bugünkü değer sıfırdır. Birden küçükse net bugünkü değer negatiftir. Değerlendirme sürecinde bağımsız projelerde bir projenin kabul edilmesi için kârlılık endeksinin birden büyük ya da bire eșit olması gerekir. Alternatif projelerde ise, kârllılı endeksi bire eşit veya daha büyük olmak koşuluyla, kârlılık endeksi daha büyük proje seçilir $(1,5,9)$.

\section{Maliyet Fayda Endeksi Yöntemi} (Cost-Benefit Index)

Sağlık hizmetleri ve sağllk kurumlarının doğası gereği projelerin yararlarını tamamen para ile ifade edilmesi imkânı bulunmamaktadır. Örneğin, yaşamın kurtarılması, doğru teşhis konulması, doğru tedavi uygulanmas1, eğitime ve ya araştırmaya katk1 yapılmas1 vb. yararların para ile ifade edilmesi imkânı bulunmamaktadir. Maliyet fayda endeksi yöntemi, parasal olarak ifade edilemeyen yararları da karar sürecine dâhil eden bir proje değerlendirme yöntemidir. Bu yöntemin esasını; net bugünkü değer yönteminin, parasal olarak ifade edilemeyen yararlar ile birlikte değerlendirilmesi oluşturmaktadır. Bir projenin parasal olarak ifade edilebilen maliyetleri ve yararları net bugünkü değer yöntemi ile değerlendirilir. Bu değerlendirmeden elde edilen sonuç projenin parasal olarak ifade edilemeyen toplam faydası ile çarpılır. Projeler büyük değerden küçük değere doğru siralanarak sağlık kurumunun bütçe imkânlarına göre karar verilir (1).

\section{Ekonomik Katma Değer Yöntemi} (Economic Value Added)

Bir yatırım projesinin getirisi, bu projenin finansmanında kullanılan kaynaklarin sermaye maliyetinden büyük ise bu proje ekonomik katma değer sağlamış olarak kabul edilir. Ekonomik katma değer yöntemini diğer 
proje değerlendirme tekniklerinden ayıran temel farklilik sermaye maliyetinin hesaplanmasindan kaynaklanmaktadır. Diğer proje değerlendirme tekniklerinde sermaye maliyeti olarak genellikle projenin finansmanında kullanılan borç kaynaklarının maliyeti sermaye maliyeti iken, ekonomik katma değer yönteminde sermaye maliyeti ağırlıklı ortalama sermaye maliyetidir. Bu yöntem kavramsal olarak maliyetkâr analizine dayanır. Buna göre bir faaliyetten elde edilen kâr, bu kârı elde etmek için kullanılan sermaye maliyetinden (borçlar ve öz kaynakların maliyeti) büyükse, bu faaliyetin değer yaratmasından söz edilebilir. Ekonomik katma değeri hesaplanan alternatif projeler arasindan büyük değere sahip olan proje belirlenerek karar verilir $(1,15)$.

Türkiye'de üniversite hastanelerinin durumu sürekli tartışılan konulardan biridir. Bu çalışmanın amacı, Ankara'daki bir kamu üniversite hastanesine alımı planlanan üç adet trbbi cihaz sistemine ait yatırım projelerinin maliyet fayda endeksi yöntemi kullanılarak değerlendirilmesidir.

\section{GEREÇ VE YÖNTEM}

Yukarıda ifade edildiği gibi maliyet fayda endeksi yöntemi projelerin hem parasal hem de parasal olmayan faydalarını değerlendiren bir yöntemdir. $\mathrm{Bu}$ nedenle araştırmada, alımı planlanan; Dijital Röntgen Sistemi, Laporoskopi/Endoskopi Sistemi ve Göz Retina Tomografisi projeleri 2012 yilı verileri kullanılarak maliyet fayda endeksi yöntemi ile değerlendirilmiştir.

Projelerin ekonomik ömrü boyunca sağlayacağ1 gelirler, günlük ve y1llık işlem sayıları ile hastane bilgi sisteminden alınan bilgiler doğrultusunda hizmeti sunan birime ait ișlem envanterinden yola çıarak hesaplanmıştır. Gelirler iki ayrı hesaplama ile tahmin edilmiştir. Birinci hesaplamada SUT fiyatları esas alınarak tahmin yapılmıştır. Bu amaçla son beş yıllık SUT işlem fiyatlarına bakılmış ve son beş yılda çalışma kapsamındaki projelerin işlemlerine ait SUT fiyatlarının değişmeyerek sabit kaldığ1 görülmüştür. SUT fiyatlarının son 5 yılda hiç değişmemesi ve hizmet sunucularının Sosyal Güvenlik Kurumu (SGK) üzerinde ki baskilarının artarak devam etmesi nedeniyle fiyatların artacağ1 öngörülmüştür. SUT fiyatlarının gelecek 5 yılda Maliye Bakanlığının son beş yeniden değerleme oranlarinin ortalamas1 olan \% 6,37 oranında artacağı öngörülmüștür. Bu parametre ve tahmin edilen işlem sayıları ile birlikte gelecek beş yılda SUT fiyatları ile beş yıllık gelir tahmini yapılmıştır.

İkinci hesaplama Türk Tabipler Birliği (TTB) Rehber Ücret Tarifesi esas alınarak yapılmıştır. Projelerin yürütüldüğü hastane Ankara da faaliyet gösterdiği için bu hesaplamalarda Ankara katsayısı esas alınmıştır. Daha sonra gerek net bugünkü değer hesaplamasinda gerekse maliyet fayda endeksinin hesaplamasinda SUT ve TTB fiyatları ile elde edilen gelir tahminleri ayrı ayrı kullanılmiştır.

Projelerin ekonomik ömrü boyunca oluşan giderler; hastane bilgi sisteminden, satin alma biriminden ve firma görüşmeleri sonucu elde edilen veriler kullanılarak hesaplanmıştır. Her bir proje için ekonomik ömür beş y1l olarak kabul edilmiş, gelir ve giderlere ilişkin tahminlerde; Maliye Bakanlığının son beş yıla ait yeniden değerleme oranlarının ortalamas1 olan $\% 6,37$ oranı iskonto oranı olarak kabul edilmiştir.

Yatırım projesi değerlendirme yöntemi olarak maliyet-fayda endeksi yöntemi kullanılmıştır. Projelere ait maliyet fayda endeksinin hesaplanması aşağıdaki formül kullanılarak yapilmıştır.

Maliyet $/$ Fayda Endeksi $=\frac{\text { Net Bugünkü Değer }}{\text { Cihazın Bugünkü Maliyeti }} \times$ Toplam Fayda

Formülden görüldüğü gibi maliyet fayda endeksinin hesaplanabilmesi için net bugünkü değerin hesaplanması ve toplam faydanin ölçülmesi gerekmektedir. Cihazların toplam faydası aşağıdaki formül kullanılarak hesaplanmıştır.

Cihazın Toplam Faydası= Fayda Değeri Toplamı X Cihazın Ekonomik Ömrü

Faydanın ölçülebilmesi için, literatür bilgileri ve İstanbul Üniversitesi Hastaneler Genel Direktörlüğünün uygulamalarından yararlanilarak fayda kategorileri ve fayda ağırlıklarını içeren tablo hazırlanmıştır. Hazırlanan bu tablo her cihaz için ilgili uzmanlar tarafindan doldurularak ilgili cihazın yıllık fayda değeri hesaplanmıştır. 
Tablo 1: Fayda-Ağırlık İlişki Tablosu

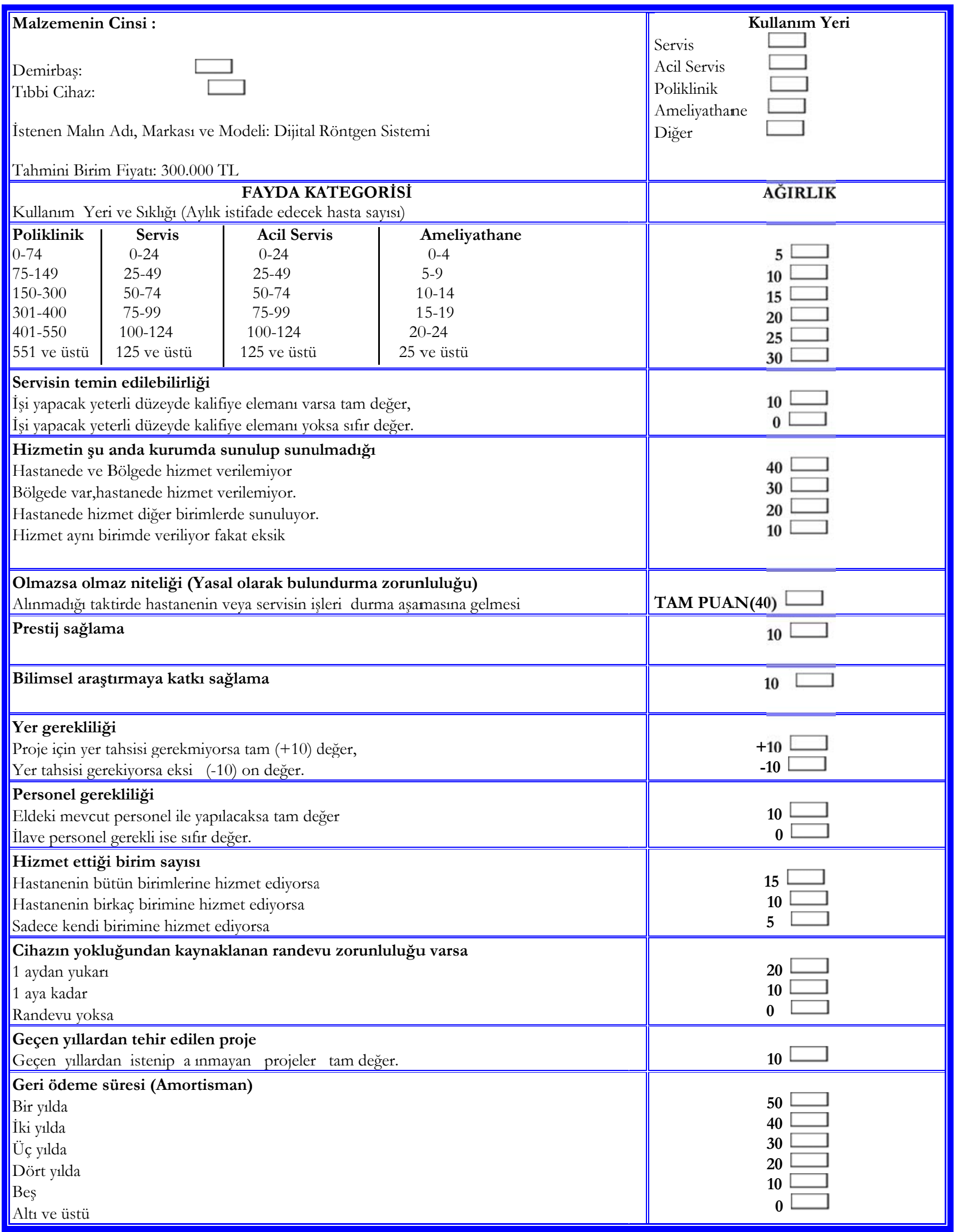




\begin{tabular}{|c|c|}
\hline $\begin{array}{l}\text { Sarf malzeme kullanımı gerekiyor mu? } \\
\text { Gerekiyorsa sıfır, } \\
\text { Gerekmiyorsa tam değer. }\end{array}$ & $\begin{array}{r}0 \\
10 \square\end{array}$ \\
\hline $\begin{array}{l}\text { İstenen cihazın proforması, alternatif teklifleri ve en az üç markayı tutan şartnameleri } \\
\text { varmı? } \\
\text { Varsa artı yirmi }(+20) \\
\text { Yoksa eksi yirmi }(-20)\end{array}$ & $\begin{array}{l}+20 \square \square \\
-20 \square \square\end{array}$ \\
\hline $\begin{array}{l}\text { Yatırımın ekonomik ömrü } \\
1-5 \text { y1l } \\
6-9 \\
10 \text { ve üstü }\end{array}$ & $\begin{aligned} & \square \\
10 & \square \\
15 & \square\end{aligned}$ \\
\hline $\begin{array}{l}\text { Beklenen Faydanın Yapısı } \\
\text { Teşhis ve Tedavi edici } \\
\text { Tedavi Edici } \\
\text { Erken Teşhis Edici } \\
\text { Teşhis Edici } \\
\text { Teşhis ve Tedaviye katkı }\end{array}$ & $\begin{array}{l}50 \square \\
40 \square \\
30 \square \\
20 \square \\
10 \square\end{array}$ \\
\hline YIILIK TOPLAM FAYDA DEĞERİ & \\
\hline YATIRIMIN EKONOMİK ÖMRÜ (YIL) & \\
\hline HAYAT BOYU FAYDA DEĞERİ & \\
\hline
\end{tabular}

\section{BULGULAR}

Araştırma kapsamında her bir proje için hem SUT fiyatları hem de TTB Rehber Ücret Tarifesi esas alınarak gider, gelir ve net nakit girişleri hesaplanmıştır. Daha sonra net bugünkü değerleri ve maliyet fayda endeksi hesaplanarak projelerin s1ralaması yapılmıştır.

1. Dijital Röntgen Sistemi Alım Projesi: Proje bilgileri aşağıda sunulmuştur:

\subsection{Ekonomik Ömrü: 5 Y⿺l}

1.2. Hizmet Miktar1: Hastane bilgi sistemi ve faturalama biriminden radyolojik incelemeler kapsaminda yapılan işlemlerinin listesi alınmıştır. İslem listesinde, radyolojik incelemenin türü, hasta sayısı, hastanın cinsiyeti ve tahakkuk durumu yer almaktadır. Radyolojik işlemler içerisinden Dijital Röntgen Sistemi ile yapilmayan incelemelere ait veriler tespit edilmiş ve bu incelemelere ait veriler hesaplamaya dahil edilmemiştir. Hastanede 2009-2012 y1llar1 arasinda hastalara tahakkuk ettirilen radyolojik işlemlere ait veriler incelenmiş ve işlem bazında hastanenin dört yıllık çekim sayılarındaki artış oranları hesaplanmıştır. Buna göre; 2009-2012 yıllarında gerçekleşmiş olan ve fatura edilen dijital röntgen sistemleri ile yapilan radyolojik inceleme sayılarına göre bir önceki y1la kıyasla değișim oranlarının ortalamas1 \%2,75 olarak hesap edilmiştir. Bu talep artışının; Dijital Röntgen Sistemi hastaneye alındığında devam edeceği ve 2015-2019 y1lları arasında geçmiş dört yıla ait değişim oranlarının ortalaması olan $\% 2,75$ oranında artacağ1 varsayılmıştır. Bu veriler yardımı ile gelecek beş yıllık işlem sayıları tahmin edilmiştir

$\mathrm{Bu}$ verilerin yardımıyla dijital röntgen cihazının iki vardiya çalışması koşuluyla çekilecek röntgen işlemi sayısı tahmin edilmiştir. Günlük ve yillık işlem sayısı hastane bilgi sisteminden gelen bilgiler doğrultusunda hizmeti sunan birime ait işlem envanterinden yola çıkılarak hesaplanmıştır. Buna göre, günlük çalışma saati dakika cinsinden baz alınıp, radyolojik işlem süresine bölünerek bulunmuştur. Günde ortalama 102,4 çekim yapılacağ1 tahmin edilmiştir. Ayda 22 işgünü varsay1- $\mathrm{m} 1$ ile y1llık çekim sayıs1; 102,4 X 22 $\mathrm{X} 12=27.033,6$ olarak tahmin edilmişstir.

1.3. Yıllık Fayda Değeri: Fayda kategorileri ve ağırlıkları tablosu ilgili uzmanlar tarafindan doldurulmuş ve yrllık fayda değerinin 200 birim olduğu tespit edilmiştir.

1.4. Dijital Röntgen Sistemi Maliyeti: $3,00.000 \mathrm{TL}$

1.5. İskonto Oranı: $\% 6,37$.

1.6. Dijital Röntgen Sistemi Gelirleri: Gereç ve yöntemde açıklandığ1 gibi SUT ve TTB fiyat tarifesi esas alınarak hesaplanmıstır.

1.7. Dijiltal Röntgen Sistemi Giderleri: Giderler aşağıdaki başlıklar altında tahmin edilmiştir.

- Amortisman Gideri: Yatırımların hastaneye mal oluş fiyatları farkl1dir. Cihazlar arasinda haksiz rekabet oluşmaması için eşit oranlı amortisman uygulanmış ve Dijital Röntgen Sistemi y1llık amortisman tutar1 60.000 TL olarak hesaplanmiştır. 
- Personel Giderleri: Radyoloji Servisinde bu sistemin kullanılması için bulunması gerekli personel; 1 Uzman Hekim, 2 Teknisyen ve 1 Memur olarak tahmin edilmiştir. Söz konusu personelin mevcut durumda maaş ve döner sermaye olarak kuruma maliyetleri tespit edilmiştir. Personel giderlerinin; gelecek beş yılda ne kadar artacağını tahmin etmek için geçmiş beş yılda memur maaşlarına yapılan zam oranlarının ortalamasi olan $\% 6,6$ kullanılmıştır. Buna göre gelecek beş yıla ait tahminler yapılmıştır.

- Bakım Onarım Giderleri: Dijital Röntgen Sistemi bakım onarım fiyatları hastane ile firma arasinda y1llık sözleşmeler ile belirlenmektedir. Firma, 2015 yılı için yıllık bakım ücretini 30.000 TL olarak teklif etmektedir. Sistem iki yll garantili olacağından kurulumuna müteakip ilk iki yıl bakım onarım gideri hesaplanmamıştır. Sonraki üç yıl için Maliye Bakanlığının yeniden değerleme oranlarının ortalaması kullanılarak bakım onarım giderleri tahmin edilmiștir.

- Değişken Giderler: Dijital Röntgen Sistemi değişken gideri X-1şını elde etmek için kullanılan X-1şın tüpü ve görüntüyü dijital bilgiye çeviren X-1șın dedektörüdür. Firma, 2015 yılı için X-1şın tüpü fiyatını 40.000 TL. teklif etmektedir ve bir tüp ile ortalama 200.000 çekim yapilabileceği varsayılmaktadır. 2015 y1lı için X-1şın dedektörü fiyatı ise 100.000 TL. teklif edilmekte ve bir X-1şın dedektörü ile ortalama 1.000 .000 çekim yapılabileceği varsayılmaktadır. Her bir görüntüleme için genel tıbbi sarf maliyeti 1,2 TL olduğu ve Maliye Bakanlığının son beş yıla ait yeniden değerleme oranlarının ortalaması kadar artacağı varsayılmıştır. Bu rakam ve yılllk çekim sayıları ile gelecek beş yıllık tahminler yapılmıştır.

Net Bugünkü Değer Hesabı: Gelir ve giderlere ilişkin tahminler yapıldıktan sonra net nakit akışlarının belirlenmesi gerekmektedir. Dijital Röntgen Sisteminin y1llar itibariyle net nakit akışları aşağıdaki gibi gerçekleşmiş olacaktır.

Tablo 2: Dijital Röntgen Sistemi Net Nakit Akışları

\begin{tabular}{|c|c|c|c|}
\hline Yillar & Gider(TL) & Gelir(TL) & NNA (TL) \\
\hline 2015 & $299.142,70$ & $250.244,74$ & $48.897,96$ \\
\hline 2016 & $314.846,75$ & $266.163,52$ & $\begin{array}{c}- \\
48.683,23\end{array}$ \\
\hline 2017 & $365.525,94$ & $283.075,47$ & $82.450,47$ \\
\hline 2018 & $385.522,78$ & $301.173,99$ & $84.348,79$ \\
\hline 2019 & $406.828,73$ & $320.378,34$ & $86.450,39$ \\
\hline
\end{tabular}

Net nakit akışları(NNA) belirlendikten sonra Dijital Röntgen Sistemi'nin net bugünkü değeri hesaplanabilir. Net bugünkü değer aşağıdaki formül kullanılarak hesaplanmıştır.

$\mathrm{NBD}=\sum_{t=1}^{n} \frac{N N A}{(1+i)^{t}}-\mathrm{I}$

Formülde; NBD=Net bugünkü değer, $\mathrm{I}=$ Başlangıçta yapılan yatırım tuta$\mathrm{r} 1$, NNA $t=\mathrm{t}$ yilinda yatırimdan beklenen net nakit akışı, $\mathrm{i}=$ İskonto oranı(sermaye maliyeti) ve $n=$ Ekonomik ömür olarak ifade edilmiștir.

Yukarıda belirtildiği üzere indirgeme oranı Maliye Bakanlığının son beş yeniden değerleme oranlarının ortalamas1 olan \% 6,30 ve ekonomik ömür beş y1ldır. Buna göre;

$$
\begin{aligned}
\mathbf{N B D}= & \frac{-48.897,96}{1+0,063}+\frac{-48.693,23}{(1+0,063)^{2}} \\
& +\frac{-82.450,47}{(1+0,063)^{3}}+\frac{-84.348,79}{(1+0,063)^{4}} \\
& +\frac{-86.450,39}{(1+0,063)^{5}}-300.000
\end{aligned}
$$

$\mathrm{NBD}=(-587.481,60 \mathrm{TL})$

SUT fiyatları esas alınarak yapılan hesaplamada Dijital Röntgen Sisteminin net bugünkü değeri $\mathbf{- 5 8 7 . 4 8 1 , 6 0}$ TL olarak bulunmuştur. Yani SUT fiyatları ile bu yatırım projesinin ge- lirleri giderlerini karşılayamamaktadir. Dolayısıyla bu yatırım projesine yatırım yapilması durumunda hastane zarar etmiş olacaktır. Çünkü yatırımın net bugünkü değeri negatiftir. Bu durumda hastanenin teknolojideki gelişmeleri izlemesi ve kendini yenilemesi imkânsız hale gelecektir.

Net bugünkü değer negatif olduğu için maliyet fayda endeksi de negatif olacaktır. Sistemin yıllık fayda değeri 200 birim olduğundan beş yılllk fayda değeri 1.000 birimdir. Değerler maliyet fayda endeksi formülünde yerine konulduğunda,

Maliyet Fayda Endeksi =

$$
\frac{-587.481,60}{300.000} \times 1.000=\underline{\mathbf{- 1 . 9 5 8 , 2 7}}
$$

SUT fiyatları esas alınarak yapılan hesaplamada Dijital Röntgen Sisteminin maliyet fayda endeksi $\mathbf{- 1 . 9 5 8 , 2 7}$ TL olarak bulunmuştur. Herhangi bir projeye yatırım yapilabilmesi için maliyet fayda endeksinin pozitif olması gerekmektedir. Dijital Röntgen Sisteminin maliyet fayda endeksi negatif olduğu için mevcut SUT fiyatları ile hastane tarafindan alınmaması gerekmektedir.

Dijital Röntgen Sisteminin net bugünkü değeri ve maliyet fayda endeksi Türk Tabipler Birliği (TTB) Rehber Ücret Tarifesi esas alınarak da hesaplanmıştır. Buna göre Dijital Röntgen Sisteminin net nakit akışları aşağıdaki gibi gerçekleşmiştir.

Tablo 3: TTB Ücret Tarifesine Göre Net Nakit Akışları

\begin{tabular}{|c|c|c|c|}
\hline Yıllar & Gider(TL) & Gelir(TL) & NNA (TL) \\
\hline 2015 & $299.142,70$ & $2.516 .655,25$ & $2.217 .512,55$ \\
\hline 2016 & $314.846,75$ & $2.677 .096,12$ & $2.362 .249,37$ \\
\hline 2017 & $365.525,94$ & $2.847 .198,00$ & $2.481 .672,06$ \\
\hline 2018 & $385.522,78$ & $3.029 .234,55$ & $2.643 .711,77$ \\
\hline 2019 & $406.828,73$ & $3.222 .393,60$ & $2.815 .564,87$ \\
\hline
\end{tabular}




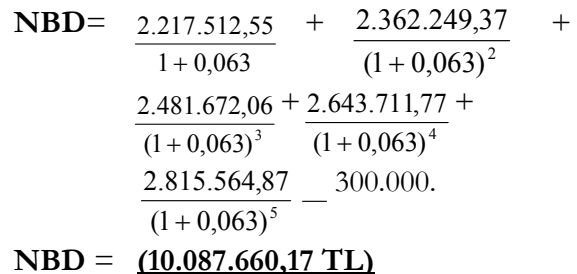

Görüldüğü gibi Türk Tabipler Birliği (TTB) Rehber Ücret Tarifesi esas alınarak hesaplama Dijital Röntgen Sisteminin net bugünkü değeri 10.087.660,17 TL olarak bulunmuştur. Yani TTB fiyatları ile bu yatırım projesinin gelirleri giderlerini karşılayabilmektedir. Dolayısıyla TTB Rehber Ücret Fiyat Tarifesi esas alındığında Dijital Röntgen Sistemi projesi hastane için yatırım yapilabilir bir proje olmaktadır.

Değerler maliyet fayda endeksi formülünde yerine konulduğunda,

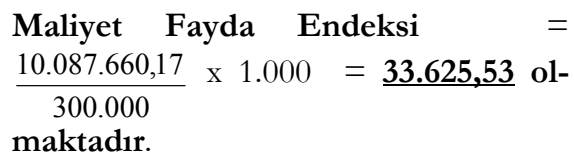

TTB fiyatları esas alınarak yapılan hesaplamada Dijital Röntgen Sisteminin maliyet fayda endeksi $\mathbf{3 3 . 6 2 5 , 5 3}$ TL olarak bulunmuștur. Dijital Röntgen Sisteminin maliyet fayda endeksi pozitif olduğu için TTB fiyatları ile hastane tarafindan alınabilir bir projedir. Ancak alım kararı verilirken diğer projeler ile birlikte öncelik sıralamasının yapılması gerekmektedir.

2. Laporoskopi/Endoskopi Sistemi Alım Projesi: Çocuk Cerrahisi ameliyathanesine kurulması planlanan sistemin bilgileri aşağıda sunulmuștur:

2.1. Ekonomik Ömrü: 5 Y1l

2.2. Hizmet Miktarı: İlgili uzman hekim tarafindan günde 5 hastaya hizmet vereceği ifade edilmiştir. Buna göre aylık 22 iş gününden hareketle y1lda (5 X 22 X 12) $=1.320$ hastaya hizmet vereceği tahmin edilmiştir. $\mathrm{Bu}$ hastalar için hastane bilgi sisteminden gelen bilgiler doğrultusunda mevcut durumda yap1lan Laporoskopi/Endoskopi işlemleri tespit edilmiş ve geleceğe yönelik işlemlerin tahmini yapılmıştır.
2.3. Yillık Fayda Değeri: Fayda kategorileri ve ağırlıkları tablosu ilgili uzmanlar tarafindan doldurulmuş ve y1llık fayda değerinin 265 birim olduğu tespit edilmiştir.

2.4. Laporoskopi/Endoskopi Sistemi Maliyeti: 120.000 TL

2.5. İskonto Oranı: $\% 6,37$.

2.6. Laporoskopi/Endoskopi Sistemi Gelirleri: Gereç ve yöntemde açıklandığı gibi SUT ve TTB fiyat tarifesi esas alınarak hesaplanmıştır.

2.7. Laporoskopi/Endoskopi Sistemi Giderleri: Giderler aşağıdaki başlıklar altında tahmin edilmiştir.

- Amortisman Gideri: Yatırımların hastaneye mal oluș fiyatları farkl1dir. Cihazlar arasinda haksiz rekabet oluşmaması için eşit oranlı amortisman uygulanmış ve Dijital Röntgen Sistemi y1llık amortisman tutar1 24.000 TL olarak hesaplanmiştır.

- $\quad$ Personel Giderleri: Çocuk Cerrahi Servisinde bu sistemin kullanılması için bulunması gerekli personel; 1 Uzman Hekim, ve 1 Hemşire olarak tahmin edilmiştir. Söz konusu personelin mevcut durumda maaş ve döner sermaye olarak kuruma maliyetleri tespit edilmiştir. Personel giderlerinin; gelecek beş yılda ne kadar artacağını tahmin etmek için geçmiş beş yılda memur maaşlarına yapilan zam oranlarının ortalamas1 olan \%6,6 kullanılmıştır. Buna göre gelecek beş yıla ait tahminler yapılmıştır.

- Bakım Onarım Giderleri: Laporoskopi/Endoskopi Sistemi bakım onarim fiyatları hastane ile firma arasında yillık sözleşmeler ile belirlenmektedir. Firma, 2015 yllı için y1llık bakım ücretini 5.000 TL olarak teklif etmektedir. Sistem iki yil garantili olacağından kurulumuna müteakip ilk iki yıl bakım onarım gideri hesaplanmamıştır. Sonraki üç yıl için Maliye Bakanlığının yeniden değerleme oranlarının ortalaması kullanılarak bakım onarım giderleri tahmin edilmiştir.
- Değişken Giderler: Laporoskopi/Endoskopi Sisteminde vücut içi görüntüleme ve girişimsel işlemlerde kullanılan endoskopların bir başka hasta için güvenle kullanılabilir hale getirilmesi zorunludur. Bu nedenle yüksek düzeyde dezenfeksiyon ve etkili bir temizleme işlemi yapilır. Temizleme ve dezenfeksiyon sırasında kullanilan tıbbi sarflar "Yüksek Düzey Dezenfektan (HLD)" ve "Endoskopik Spot Marker"dır. Firma, 2015 yılı için 5 litrelik HLD ve spot marker fiyatını 65 TL. teklif etmektedir ve ortalama 20 kez dezenfeksiyon yapilabileceği varsayılmaktadır.

Her bir laporoskopik/endoskopik işlem için genel tıbbi sarf maliyeti 3,25 TL olduğu ve Maliye Bakanl1ğının son beş yıla ait yeniden değerleme oranlarınin ortalaması kadar artacağ1 varsayılmıştır. Bu rakam ve yıllık çekim sayıları ile gelecek beş yıllık tahminler yapılmıştır.

Net Bugünkü Değer Hesabı: Gelir ve giderlere ilişkin tahminler yapıldıktan sonra net nakit akışlarının belirlenmesi gerekmektedir. Laporoskopi/Endoskopi Sisteminin y1llar itibariyle net nakit akışları aşağıdaki gibi gerçekleşmiş olacaktır.

Tablo 4: Laporoskopi/Endoskopi Sistemi Net Nakit Akışları

\begin{tabular}{|c|c|c|c|}
\hline Yıllar & Gider(TL) & Gelir(TL) & NNA (TL) \\
\hline 2015 & 152.878 & 281.128 & $128.249,70$ \\
\hline 2016 & 161.374 & 299.033 & $137.658,97$ \\
\hline 2017 & 176.087 & 318.079 & $141.992,45$ \\
\hline 2018 & 186.099 & 338.341 & $152.241,88$ \\
\hline 2019 & 196.772 & 359.894 & $163.122,48$ \\
\hline
\end{tabular}

$$
\begin{aligned}
\mathbf{N B D}= & \frac{128.249,70}{1+0,063}+\frac{137.658,97}{(1+0,063)^{2}}+ \\
& \frac{141.992,45}{(1+0,063)^{3}}+\frac{152.241,88}{(1+0,063)^{4}}+ \\
& \frac{163.122,48}{(1+0,063)^{5}}-120.000 .
\end{aligned}
$$

$\mathrm{NBD}=\underline{(480.105,82 \mathrm{TL})}$ 
SUT fiyatları esas alınarak yapılan hesaplamada Laporoskopi/Endoskopi Sistemi yatırım projesinin net bugünkü değeri 480.105,82 TL olarak bulunmuştur. Yani SUT fiyatları ile bu yatırım projesinin gelirleri giderlerini karşılayabilmektedir. Net bugünkü değer pozitif olduğu için hastane açısından yatırım yapılabilir bir projedir. Ancak daha sağllklı değerlendirme yapabilmek için maliyet fayda endeksini de hesaplamak gerekmektedir.

Net bugünkü değeri hesaplanan projenin maliyet fayda endeksini hesaplayalım. Sistemin y1llık fayda değeri 265 birim olduğundan beş yıllık fayda değeri 1.325 birimdir. Değerler fayda endeksi formülünde yerine konulduğunda,

Maliyet Fayda Endeksi $=\frac{480.105,82}{120.000} \mathrm{x}$ $1.325=\underline{\mathbf{5} .301,16}$ olmaktadır

SUT fiyatları esas alınarak yapilan hesaplamada Laporoskopi/Endoskopi Sisteminin maliyet fayda endeksi 5.301,16 TL olarak bulunmuștur. Herhangi bir projeye yatırım yap1labilmesi için maliyet fayda endeksinin pozitif olması gerekmektedir. Laporoskopi/Endoskopi Sisteminin maliyet fayda endeksi pozitif olduğu için SUT fiyatları ile hastane tarafindan alınabilir bir projedir. Ancak alım kararı verilirken diğer projeler ile birlikte öncelik sıralamasının yapılması gerekmektedir.

Laporoskopi/Endoskopi Sisteminin net bugünkü değeri ve maliyet fayda endeksi Türk Tabipler Birliği (TTB) Rehber Ücret Tarifesi esas alınarak da hesaplanmıştır. Buna göre Laporoskopi/Endoskopi Sisteminin net nakit akışları aşağıdaki gibi gerçekleşmiştir.

Tablo 5: TTB Ücret Tarifesine Göre Net Nakit Akışları

\begin{tabular}{|c|c|c|c|}
\hline Yıllar & Gider(TL) & Gelir(TL) & NNA (TL) \\
\hline 2015 & 152.878 & $1.003 .077,61$ & $850.199,25$ \\
\hline 2016 & 161.374 & $1.066 .973,65$ & $905.599,82$ \\
\hline 2017 & 176.087 & $1.134 .939,88$ & $958.853,25$ \\
\hline 2018 & 186.099 & $1.207 .235,55$ & $1.021 .136,09$ \\
\hline 2019 & 196.772 & $1.284 .136,45$ & $1.087 .364,89$ \\
\hline
\end{tabular}

$$
\begin{aligned}
\mathbf{N B D}= & \frac{850.199,25}{1+0,063}+\frac{905.599,82}{(1+0,063)^{2}}+ \\
& \frac{958.853,25}{(1+0,063)^{3}}+\frac{1.021 .136,09}{(1+0,063)^{4}}+ \\
& \frac{1.087 .364,89}{(1+0,063)^{5}}-120.000 .
\end{aligned}
$$

$\mathrm{NBD}=(3.880 .407,84 \mathrm{TL})$

Görüldüğü gibi Türk Tabipler Birliği (TTB) Rehber Ücret Tarifesi esas alınarak hesaplama Laporoskopi/Endoskopi Sisteminin net bugünkü değeri 3.880.407,84 TL olarak bulunmuştur. Yani TTB fiyatlar1 ile bu yatırım projesinin gelirleri giderlerini karşılayabilmektedir. Dolayısıla TTB Rehber Ücret Fiyat Tarifesi esas alındığında Laporoskopi/Endoskopi Sistemi projesi hastane için yatırım yapılabilir bir proje olmaktadır.

Değerler maliyet fayda endeksi formülünde yerine konulduğunda,

Maliyet Fayda Endeksi $=\frac{3.880 .407,84}{120.000}$ $\mathrm{x} 1.325=\underline{42.846,16}$ olmaktadır

TTB fiyatları esas alınarak yapilan hesaplamada Laporoskopi/Endoskopi Sisteminin maliyet fayda endeksi 42.846,16 TL olarak bulunmuştur. Laporoskopi/Endoskopi Sisteminin maliyet fayda endeksi pozitif olduğu için TTB fiyatları ile hastane tarafindan alınabilir bir projedir. Ancak alım kararı verilirken diğer projeler ile birlikte öncelik sıralamasının yapılması gerekmektedir.

3. Göz Retina Tomografi Sistemi Alım Projesi: Bu cihaz ile Optik Koherens Tomografisi (Optical Coherence Tomography, OCT) işlemi yapilmaktadır. Proje bilgileri aşağıda sunulmuştur.

\subsection{Ekonomik Ömrü: 5 Y1l}

3.2. Hizmet Miktarı: Hastanenin ilgili uzman hekimi tarafindan; günde ortalama 12 hastaya OCT tetkiki yapılabileceği bildirildiğinden yılda bakılabilecek hasta sayısı (12 X 22
$X$ 12) = 3.168 olduğu tahmin edilmiştir.

3.3. Yıllık Fayda Değeri: Fayda kategorileri ve ağırlıkları tablosu ilgili uzmanlar tarafindan doldurulmuş ve yıllık fayda değerinin 135 birim olduğu tespit edilmiştir.

3.4. Göz Retina Tomografi Sistemi Maliyeti: 145.000 TL

3.5. İskonto Oranı: $\% 6,37$.

3.6. Göz Retina Tomografi Sistemi Gelirleri: Gereç ve yöntemde açıklandığ1 gibi SUT ve TTB fiyat tarifesi esas alınarak hesaplanmıştır.

3.7. Göz Retina Tomografi Sistemi Giderleri: Giderler aşağıdaki başlıklar altında tahmin edilmiştir.

- Amortisman Gideri: Yatırımların hastaneye mal oluş fiyatları farkl1dir. Cihazlar arasinda haksiz rekabet oluşmaması için eşit oranlı amortisman uygulanmış ve Göz Retina Tomografi Sistemi y1llik amortisman tutar1 29.000 TL olarak hesaplanmıştır.

- Personel Giderleri: Göz Hastalıklar1 Servisinde bu sistemin kullanılması için bulunması gerekli personel; 1 Uzman Hekim ve $1 \mathrm{Hem}-$ şire olarak tahmin edilmiştir. Söz konusu personelin mevcut durumda maaş ve döner sermaye olarak kuruma maliyetleri tespit edilmiştir. Personel giderlerinin; gelecek beş yılda ne kadar artacağını tahmin etmek için geçmiş beş y1lda memur maaşlarına yapılan zam oranlarının ortalaması olan \%6,6 kullanılmıştır. Buna göre gelecek beş yıla ait tahminler yapılmıştır.

- Bakım Onarım Giderleri: Göz Retina Tomografi Sistemi bakım onarım fiyatları hastane ile firma arasında yıllık sözleşmeler ile belirlenmektedir. Firma, 2015 y1lı için yıllık bakım ücretini 10.000 TL olarak teklif etmektedir. Sistem iki yll garantili olacağından kurulumuna müteakip ilk iki yıl bakım onarım gideri hesaplanmamıştır. Sonraki üç yıl için Maliye Bakanlığının yeniden değerleme oranlarının ortalaması 
kullanılarak bakım onarım giderleri tahmin edilmiştir.

- Değişken Giderler: Değişken gideri bulunmamaktadır.

Net Bugünkü Değer Hesabı: Gelir ve giderlere ilişkin tahminler yapıldıktan sonra net nakit akışlarının belirlenmesi gerekmektedir. Göz Retina Tomografi Sisteminin yillar itibariyle net nakit akışları aşağıdaki gibi gerçekleşmiş olacaktır.

Tablo 6: Göz Retina Tomografi Sistemi Net Nakit Akışları

\begin{tabular}{|c|c|c|c|}
\hline Yıllar & Gider(TL) & Gelir(TL) & NNA (TL) \\
\hline 2015 & $174.099,66$ & $80.761,19$ & $-93.338,47$ \\
\hline 2016 & $183.676,23$ & $85.912,99$ & $-97.763,24$ \\
\hline 2017 & $205.199,44$ & $91.392,36$ & $-113.807,08$ \\
\hline 2018 & $216.802,59$ & $97.229,09$ & $-119.573,50$ \\
\hline 2019 & $229.169,88$ & $103.393,38$ & $-125.776,50$ \\
\hline
\end{tabular}

$\mathrm{NBD}=$

$\frac{-93.338,47}{1+0,063}+\frac{-97.763,24}{(1+0,063)^{2}}$

$+\frac{-113.807,08}{(1+0,063)^{3}}+\frac{-119.573,50}{(1+0,063)^{4}}+$

$\frac{-125.776,50}{(1+0,063)^{5}}-145.000$.

$\mathrm{NBD}=\underline{(-558.149,58)}$

SUT fiyatları esas alınarak yapılan hesaplamada Göz Retina Tomografi Sisteminin net bugünkü değeri 558.149,58 TL olarak bulunmuştur. Yani SUT fiyatlar1 ile bu yat1rım projesinin gelirleri giderlerini karşılayamamaktadır. Dolayısıyla bu yatırım projesine yatırım yapilması durumunda hastane zarar etmiş olacaktır. Çünkü yatırımın net bugünkü değeri negatiftir. Bu durumda hastanenin teknolojideki gelişmeleri izlemesi ve kendini yenilemesi imkânsız hale gelecektir.

Net bugünkü değer negatif olduğu için maliyet fayda endeksi de negatif olacaktır. Yıllık fayda değeri 135 birim olduğundan beş yıllık fayda değeri 675 birimdir. Değerler maliyet fayda endeksi formülünde yerine konulduğunda,

\section{Maliyet Fayda Endeksi =}

$$
\frac{-558.149,58}{145.000} \times 675=\underline{-2.598,27}
$$

\section{olmaktadır}

SUT fiyatları esas alınarak yapılan hesaplamada Göz Retina Tomografi Sisteminin maliyet fayda endeksi 2.598,27 TL olarak bulunmuştur. Herhangi bir projeye yatırım yap1labilmesi için maliyet fayda endeksinin pozitif olmasi gerekmektedir. Göz Retina Tomografi Sisteminin maliyet fayda endeksi negatif olduğu için mevcut SUT fiyatları ile hastane tarafindan alınmaması gerekmektedir.

Göz Retina Tomografi Sisteminin net bugünkü değeri ve maliyet fayda endeksi Türk Tabipler Birliği (TTB) Rehber Ücret Tarifesi esas alınarak da hesaplanmıştır. Buna göre Göz Retina Tomografi Sisteminin net nakit akışları aşağıdaki gibi gerçekleşmiştir.

Tablo 7: TTB Ücret Tarifesine Göre Net

\begin{tabular}{|c|c|c|c|}
\hline \multicolumn{4}{|c|}{ Nakit Akışları } \\
\hline 2015 & $174.099,66$ & $962.940,21$ & $788.840,55$ \\
\hline 2016 & $183.676,23$ & $1.024 .285,36$ & $840.609,13$ \\
\hline 2017 & $205.199,44$ & $1.089 .531,59$ & $884.332,15$ \\
\hline 2018 & $216.802,59$ & $1.158 .946,91$ & $942.144,32$ \\
\hline 2019 & $229.169,88$ & $1.232 .769,54$ & $1.003 .599,66$ \\
\hline
\end{tabular}

$$
\begin{aligned}
\mathbf{N B D}= & \frac{788.840,55}{1+0,063}+\frac{840.609,13}{(1+0,063)^{2}} \\
& +\frac{884.332,15}{(1+0,063)^{3}}+\frac{942.144,32}{(1+0,063)^{4}} \\
& +\frac{1.003 .599,66}{(1+0,063)^{5}}-145.000 .
\end{aligned}
$$

$\mathrm{NBD}=(3.554 .547,59 \mathrm{TL})$

Görüldüğü gibi Türk Tabipler Birliği (TTB) Rehber Ücret Tarifesi esas alınarak hesaplama Göz Retina Tomografi Sisteminin net bugünkü değeri 3.554.547,59 TL olarak bulunmuştur. Yani TTB fiyatları ile bu yatırım projesinin gelirleri gider- lerini karşlayabilmektedir. Dolay1siyla TTB Rehber Ücret Fiyat Tarifesi esas alındığında Göz Retina Tomografi Sisteminin projesi hastane için yatırım yapılabilir bir proje olmaktadır.

Değerler maliyet fayda endeksi formülünde yerine konulduğunda,

Maliyet Fayda Endeksi =

$$
\begin{aligned}
& \frac{3.554 .547,59}{145.000} \times 675=\underline{16.547,03} \\
& \text { olmaktadir. }
\end{aligned}
$$

TTB fiyatları esas alınarak yapilan hesaplamada Göz Retina Tomografi Sisteminin maliyet fayda endeksi 16.547,03 TL olarak bulunmuştur. Göz Retina Tomografi Sisteminin maliyet fayda endeksi pozitif olduğu için TTB fiyatları ile hastane tarafindan alınabilir bir projedir. Ancak alım kararı verilirken diğer projeler ile birlikte öncelik siralamas1nin yapılması gerekmektedir.

\section{Sonuç ve Öneriler}

Bu çalıșmada maliyet fayda analizi yöntemi kullanılarak, Ankara da faaliyet gösteren bir kamu üniversite hastanesinde yatırım yapılması düşünülen Dijital Röntgen Sistemi, Laporoskopi/Endoskopi Sistemi, Göz Retina Tomografi Sistemi projeleri SUT ve TTB "Rehber Ücret Fiyat Tarifesi" esas alınarak değerlendirilmiştir. Maliyet fayda analizi yönteminde projelerin öncelik siras maliyet fayda endeksleri büyükten küçüğe doğru sıralanarak belirlenmektedir. Buna göre projelere ait değerlendirme sonuçları aşağıdaki tablolarda tabloda verilmiştir.

Tablo 8: Projelerin SUT Fiyatları ile MaliyetFayda Endeksine Göre Sıralaması

\begin{tabular}{|c|l|c|}
\hline $\begin{array}{c}\text { SIra } \\
\text { No }\end{array}$ & \multicolumn{1}{|c|}{ PROJE ADI } & $\begin{array}{c}\text { SUT'A GÖRE } \\
\text { MFE }\end{array}$ \\
\hline 1 & $\begin{array}{l}\text { Laporosko- } \\
\text { pi/Endoskopi } \\
\text { Sistemi }\end{array}$ & $5.301,16$ \\
\hline 2 & $\begin{array}{l}\text { Dijital Röntgen } \\
\text { Sistemi }\end{array}$ & $-1.958,27$ \\
\hline 3 & $\begin{array}{l}\text { Göz Retina Tomog- } \\
\text { rafi Sistemi }\end{array}$ & $-2.598,27$ \\
\hline
\end{tabular}

Görüldüğü gibi, Maliyet-Fayda Endeksi (MFE)'ne göre SUT fiyatları esas alınarak yapılan değerlendirmede yatırım yapilabilecek tek proje Laporoskopi/Endoskopi Sistemi projesidir. 
Tablo 9: Projelerin TTB Fiyatları ile MaliyetFayda Endeksine Göre Sıralaması

\begin{tabular}{|c|l|c|}
\hline S.NU. & \multicolumn{1}{|c|}{ PROJE ADI } & $\begin{array}{c}\text { TTB'YE GÖRE } \\
\text { MFE }\end{array}$ \\
\hline 1 & $\begin{array}{l}\text { Laporoskopi/Endoskopi } \\
\text { Sistemi }\end{array}$ & $42.846,16$ \\
\hline 2 & Dijital Röntgen Sistemi & $33.625,53$ \\
\hline 3 & $\begin{array}{l}\text { Göz Retina Tomografi } \\
\text { Sistemi }\end{array}$ & $16.547,03$ \\
\hline
\end{tabular}

TTB Rehber Ücret Fiyat Tarifesine göre her üç projenin maliyet fayda endeksi de pozitif olarak hesaplanmış ve projelerin öncelik sırası belirlenmiştir. Buna göre hastanenin öncelik sıralamasın1; Laporoskopi/Endoskopi Sistemi Projesi, Dijital Röntgen Sistemi Projesi, Göz Retina Tomografi Sistemi Projesi şeklinde belirlemesi ve mali imkânlarına göre alımda bu sıralamaya uymasında yarar bulunmaktadır.

\section{KAYNAKLAR}

1. Ağırbaş İ. Sağlık Kurumlarında Finansal Yönetim ve Maliyet Analizi. Ankara: Siyasal Kitabevi; 2014.

2. Modigliani, F., Miller, M.H. The Cost of Capital Corporation Finance and The Theory of Investment, The American Economic Review Jan65; Vol. 55, Issue 3, p. 524527.

3. Ercan, M.K. Ban, Ü. Değere Dayalı İşletme Finansı Finansal Yönetim, 2. Bask1, Ankara: Gazi Kitabevi; 2005.

4. Bal H. Sermaye Bütçelemesi Yatırım Kararlarında Özkaynağa Nakit Akımı Yönetiminin Kullanılması İle Karşılaştırılması, Gazi Üniversitesi İktisadi ve İdari Bilimler Fakültesi Dergisi 2009; 11/1, 219-236.

5. Akbulut Y., ve Doğanay Payziner P. Sağlık Kurumlarında Finansal YürütmeDuran Varlıkların Yönetimi, (İçinde Sağlık Kurumlarında Finansal Yönetim) Editör: İsmail AĞIRBAŞ, Anadolu Üniversitesi Yayınları, Anadolu Üniversitesi Yayın No:
Üniversite hastanelerinden hizmet alan hastaların yaklaşık \%95'nin tedavi giderleri Sosyal Güvenlik Kurumu tarafindan SUT fiyatlarına göre ödenmektedir. Araștırma bulgularından anlaşılacağ gibi mevcut SUT fiyatları üniversite hastanelerini olumsuz olarak etkilemekte ve bu kurumları ya yatırım yapmamak ya da zararına hizmet sunmak ikilemi ile karşı karşıya bırakmaktadır. $\mathrm{Bu}$ nedenle bilimsel maliyet analizi çalışmaları esas alınarak SUT fiyatlarının yükseltilmesine ivedilikle gereksinim bulunmaktadır.

$\mathrm{Bu}$ süreçte hastane yöneticileri tarafindan da yapılması gereken işlemler bulunmaktadır. Çünkü amaç sınırlı kaynakları maksimum fayda sağla-

2863, Açıköğretim Fakültesi Yayın No: 1820, Eskişehir; 2013.

6. Hughes, D., McGuire, A. Stochastic Demand, Production Responses and Hospital Costs. Journal of Health Economics 2003; 22.

7. Ceydeli N. Hastane İşletmelerinde Yenileme Yatırım Kararları ve Bir Üniversite Hastanesi Radyoloji Bölümünde Uygulama. Yayınlanmamış Yüksek Lisans Tezi, 2006.

8. Gapenski, L.C. Heatlthcare Finance: An Introduction to Accounting and Financial Management, Fourt Edition, AUPHA; 2008.

9. Sarıaslan H. Yatırım Projelerinin Hazırlanması ve Değerlendirilmesi, Gözden Geçirilmiş 6. Bası, Ankara: Turhan Kitabevi; 2010.

10. Akgüç, Ö. Finansal Yönetim. İstanbul: Avciol Basım Yayın; 1998. yacak şekilde kullanmaktır. Proje değerlendirme teknikleri sağlık kurumları finansal yöneticilerinin bu süreçte kullanabilecekleri etkili bir araçtır. Bu teknikler hastane yöneticilerine faklı açılardan değerlendirme yapma imkanı da vermektedir. Maliyet fayda endeksi yöntemi sağlık kurumlarının yapısına daha uygun olduğu için değerlendirmelerde bu yöntemin esas alınması yararlı olacaktır. Hastane yönetimi, proje seçimini maliyet fayda endeksine göre belirlediğinde yatırıma ayıracağ1 kıt kaynaklarını rasyonel olarak kullanacak ve maksimum faydayı sağlayan projeye yatırmış olacaktır.

11. Needles Belverd E., Powers Marian, Crosson Susan V., Financial and Managerial Accounting. USA: Houghon Mifflin Company; 2008, p.1184.

12. Tekin Z. Sermaye Bütçelemesinde Geleneksel Yöntemlere Alternatif Olarak Reel Opsiyonlar Yöntemi. Yayınlanmamış Yüksek Lisans Tezi, 2014.

13. Erdoğan, M. Finansal Yönetim. 4. Basım, İstanbul: Aktif Yayınevi; 2009.

14. Cudi, G.,T. Finansal Yönetim İlkeleri. Doğuş Üniversitesi, Yayın No:1,İstanbul; 2007.

15. Yılgör, A.G. İşletme Performansının Değerlendirilmesinde Ekonomik Katma Değer (EVA) ve Piyasa Katma Değeri (MVA) Yöntemleri ve Bu Yöntemlerin Hisse Senedi Getirilerini Açıklama Gücünün İncelenmesi: İMKB 100 Örneği, Ankara Üniversitesi, SBF Dergisi 2005;60-61. 